\title{
Water Quality in Micro-watersheds Under Different Land Uses in the Municipality of Alegre, Espírito Santo
}

\author{
Milena Scaramussa Pastro ${ }^{1}$, Roberto Cecílio ${ }^{1}$, Sidney Zanetti ${ }^{1}$, Atanásio Amaral ${ }^{2}$, \\ Giovanni Garcia ${ }^{1}$ \\ ${ }^{1}$ Universidade Federal do Espirito Santo - UFES, Jerônimo Monteiro/ES, Brasil \\ ${ }^{2}$ Instituto Federal de Educação Ciência e Tecnologia do Espírito Santo - IFES, Rive/ES, Brasil
}

\begin{abstract}
The present study aimed to evaluate water quality attributes in micro-watersheds under different soil uses. Therefore, four micro-watersheds under the following vegetation cover were selected: pasture, primary forest reforestation, forest, and coffee plantation. Surface and underground water sampling was performed bimonthly between February and December 2014, where thermotolerant coliforms, dissolved oxygen, total nitrogen, phosphorus, turbidity, temperature, $\mathrm{pH}$, biochemical demand for oxygen and total solids were analyzed. Descriptive analyses of each variable were performed during dry and rainy periods, and the values were compared with the normative standards established by Brazilian legislation. Water Quality Indices (WQIs) were also calculated for each collection site. All sites presented some type of nonconformity with human consumption standards. The highest WQI values were found in the forest area micro-basin, followed by the coffee plantation and pasture area micro-basins, highlighting the importance of forested areas for water quality.
\end{abstract}

Keywords: water resources, water quality, vegetation cover. 


\section{INTRODUCTION}

Intense population growth and the search for economic development have increased pressure on natural resources, especially on water, resulting in a reduction in the quality of many springs and the emergence of a significant challenge for mankind: to ensure water availability, at a quality suitable for multiple uses for both current and future generations. This is a challenge recognized by the National Water Resources Policy (PNRH - Política Nacional de Recursos Hídricos) and highlighted as one of its main objectives (Brasil, 1997).

Despite having significant water resources, a crisis in water availability has emerged in Brazil. As a historical process, the replacement of native forests by extensive agricultural and pasture areas has led to changes in the hydrological cycle, resulting in changes in water availability and quality. These innumerable interventions in natural cycles and their consequences have stimulated studies into water quality related to land use and occupation. Through these studies, it has been possible to observe how different soil uses interfere in differently with water quality (Perazzoli et al., 2013; Pinto et al., 2012; Vanzela et al., 2010).

Several variables are used in water quality studies, necessitating a technical synthesis of the data via the Water Quality Index (WQI), which is widely used in Brazil and provides information that is more accessible and comprehensible for the general public (Almeida \& Schwarzbold, 2003; ANA, 2014; Von Sperling, 2005). The Index was created by the National Sanitation Foundation and adapted by the Environmental Company of the state of São Paulo, and has been used by sanitation companies and studies related to water monitoring and quality diagnostics such as the one by Batalha et al. (2014).

Throughout the Brazilian historical process, the Atlantic Forest biome was one of the most degraded. However, despite this, the State of Espirito Santo has few studies related to land use and water quality. Among the twelve drainage basins that exist in this state, the Itapemirim River Basin stands out as the main support for development in the south of the state, serving $14 \%$ of the population.

Therefore, given the importance of studies on land use and soil occupation in the management of water resources and the economic, social and environmental relevance of the Itapemirim River Basin in the State of Espirito Santo, the present study aimed to evaluate the water quality in micro drainage basins with different vegetation covers located in the municipality of Alegre-ES, and belonging to the Itapemirim River Basin.

\section{MATERIAL AND METHODS}

The study area is located in the Corrego Horizonte Sub-basin (Figure 1), located in the city of Alegre-ES in the south of Espirito Santo State, belonging to the Itapemirim River Basin. According to Köppen's classification, the region's climate type is "Cwa", Humid subtropical, with cold and dry winters (Alvares et al., 2013).

The studies were conducted in four micro-basins, which were selected due to presenting characteristics representative of the basin to which they belong and for being close together and therefore subject to similar climatic conditions (Figure 1). The basins differ according to soil use including pasture, reforestation, forest and coffee plantation.

Regarding the pasture micro-basin, water samples were collected from the spring (PS), from the lentic environment (PLe) and the lotic environment (PLo). Sampling of underground water (RU) was only possible from the reforestation area micro-basin. The micro-basin in the forest area has been a natural reforestation area for 50 years, classified as Semi-deciduous Seasonal Forest, and in this case, samples were taken from the underground water $(\mathrm{FU})$ and the lentic environment (FLe). For the coffee plantation micro-basin, water samples were collected from the lentic environment (CLe) and from the spring (CS).

The variables analyzed were: thermotolerant coliforms, dissolved oxygen, total nitrogen, $\mathrm{PO}_{4}^{3-}$, turbidity, total solids, temperature, $\mathrm{pH}$ and biochemical oxygen demand (BOD). Water sampling was performed bimonthly from February 2014 to December 2014, totaling 48 samples. Sampling was always conducted after a drought period of at least three days in order to minimize the influence of precipitation at the collection site. One-liter polyethylene bottles were used for collection, with sterilization performed only for microbiological analysis (thermotolerant coliforms). 


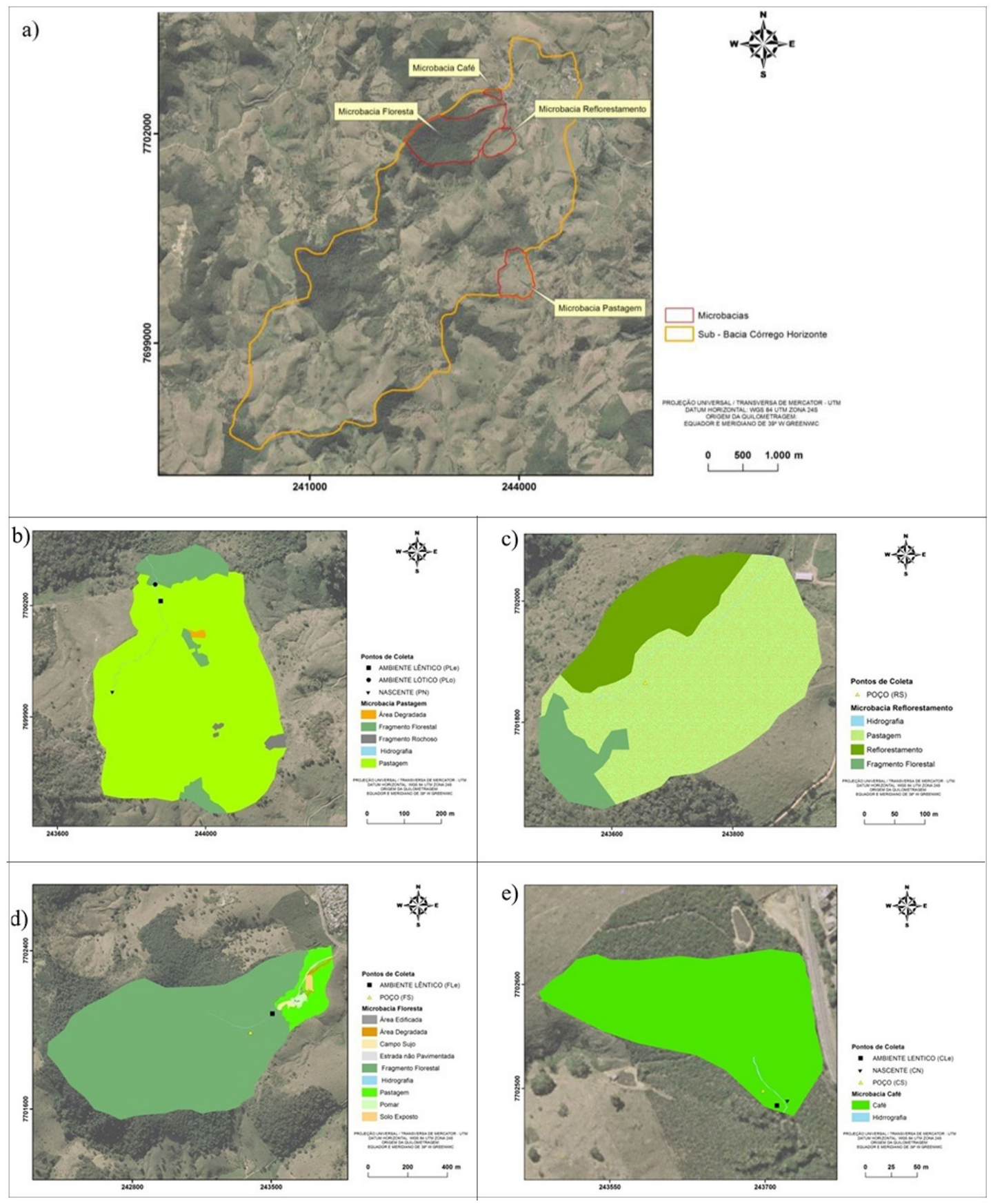

Figure 1. Micro-basins studied in the Corrego Horizonte Sub-basin in 2014: (a) location; (b) micro-basin under pasture; (c) micro-basin under reforestation; (d) micro-basin under forest; (e) micro-basin under coffee plantation.

A triple rinsing of the bottles was performed for the other analyses using water from the sampling site.

Surface water sampling methods followed NBR 9898 (ABNT, 1987). The samples were conditioned in polystyrene boxes with ice for preservation from the time of collection until being transported to the laboratory.
Temperature and dissolved oxygen (DO) were obtained directly in the field with a portable oximeter (Hanna, HI 4196). The pH and thermotolerant coliforms were analyzed immediately upon arrival at the laboratory, with the first being measured using a bench potentiometer (Marconi, PA 200). Phosphorus 
and total nitrogen were analyzed using multiparameter equipment (Hanna HI 83214), with results obtained right after reading.

Determination of thermotolerant coliforms followed the most probable number (MPN) methodology, also known as multi-tube technique, as described in the "Standard methods for the examination of water and waste water" (Eaton et al., 2005). BOD was determined by iodometric titration in accordance with NBR 12614 (ABNT, 1992). The solids series was obtained by the gravimetric method in accordance with NBR 10664 (ABNT, 1989).

Thermotolerant coliform analyses were carried out in the Laboratory of Aquatic Ecology Production of Plankton of the Federal Institute of Espirito Santo, Campus Alegre. The other analyses were carried out in the Laboratory of Water Resources of the Federal University of Espirito Santo, Campus Jeronimo Monteiro.

Two averages were calculated for each variable under analysis; one for the dry period and another for the rainy season, and then represented in tables for consideration and analysis of the behavior of each variable at all sampling sites.

Equation 1 was used to calculate the Water Quality Index (WQI). It has also used in other studies related to water quality in Espirito Santo (Souza, 2011; Agrizzi, 2012; Bertossi et al., 2013; Menezes et al., 2013). The weights established for each WQI variable were assigned according to Chart 1 , in which the classification of the water bodies was carried out using the range assigned to the State where the study areas are inserted (Chart 2).

$$
W Q I=\prod_{i=1}^{n}\left(q_{i}\right)^{w_{i}}
$$

in which: WQI: water quality index, dimensionless ranging from zero to $100 ; q_{i}$ : quality of the i-th variable, dimensionless ranging from zero to 100 obtained from the respective quality chart according to its measurement (analysis result); $\mathrm{w}_{\mathrm{i}}$ : weight corresponding to the $\mathrm{i}$-th variable, fixed according to its importance for the overall conformation of quality, dimensionless value between 0 and 1 and the sum of ' $w$ ' of all parameters is equal to 1 (Equation 2):

$\sum_{i=1}^{n} w_{i}=1$
Chart 1. WQI - Water Quality Parameters and their respective weights.

\begin{tabular}{|lc|}
\multicolumn{1}{c}{ Variable } & Weight $(\mathrm{w})$ \\
\hline Dissolved oxygen & 0.17 \\
Thermotolerant coliforms & 0.15 \\
pH & 0.12 \\
BOD & 0.10 \\
Water temperature & 0.10 \\
Total nitrogen & 0.10 \\
Phosphorus & 0.10 \\
Turbidity & 0.08 \\
Total solids & 0.08 \\
\hline
\end{tabular}

Source: CETESB (2014).

Chart 2. WQI range classification.

\begin{tabular}{|cc|}
\hline WQI-CETESB ranges & Class \\
\hline $80-100$ & Excellent \\
$52-79$ & Good \\
$37-51$ & Fair \\
$20-36$ & Bad \\
$0-19$ & Poor \\
\hline
\end{tabular}

Source: ANA (2014).

The $\mathrm{q}_{\mathrm{i}}$ of the DO was determined according to the CETESB recommendations (2014), based on the conversion of the DO value into DO Saturation Percentage (Equations 3 and 4).

$C_{s}=\left(\begin{array}{l}14.62-0.3898 \text { Temp }+ \\ 0.006969 \text { Temp }^{2}- \\ 0.00005896 \text { Temp }^{3}\end{array}\right)(1-0.0000228675 \text { Alt })^{5.167}$

$P S O=100 \frac{O D}{C_{s}}$

in which: Cs: concentration saturation of dissolved oxygen, $\mathrm{mg} \mathrm{L}^{-1}$; Temp: water temperature; ${ }^{\circ} \mathrm{C}$; Alt: altitude, m; PSO: percentage saturation of dissolved oxygen; $\%$; and DO: concentration of dissolved oxygen in the water, $\mathrm{mg} \mathrm{L}^{-1}$.

\section{RESULTS AND DISCUSSION}

Mean values for rainy and dry periods of the water quality variables monitored at each sampling point for the studied micro-basins are presented in Table 1.

When analyzing the values presented in Table 1 in the present study, we can highlight that only underground water was found in the micro-basin under reforestation 
Table 1. Mean values for rainy and dry periods of water quality variables analyzed in the studied micro-basins.

\begin{tabular}{|c|c|c|c|c|c|c|c|c|c|}
\hline \multirow{2}{*}{ Parameter } & \multirow{2}{*}{ Period } & \multicolumn{8}{|c|}{ Collection site } \\
\hline & & PS & Ple & Plo & RU & FU & Fle & Cle & CS \\
\hline \multirow{2}{*}{ Turbidity (UNT) } & Rainy & 5.64 & 55.33 & 12.00 & 168.00 & 5.47 & 59.07 & 17.13 & 0.37 \\
\hline & Dry & 1.00 & 208.57 & 20.02 & - & 1.71 & 27.70 & 6.64 & 0.19 \\
\hline \multirow{2}{*}{ Total solids $\left(\mathrm{mg} \mathrm{L}^{-1}\right)$} & Rainy & 146 & 250 & 226 & 863 & 123 & 162 & 151 & 106 \\
\hline & Dry & 130 & 436 & 263 & - & 118 & 106 & 119 & 107 \\
\hline \multirow{2}{*}{ Temperature $\left({ }^{\circ} \mathrm{C}\right)$} & Rainy & 26.2 & 25.8 & 25.7 & 26.3 & 26.7 & 28.7 & 27.3 & 26.4 \\
\hline & Dry & 25.0 & 23.2 & 22.4 & - & 25.3 & 25.1 & 25.5 & 25.0 \\
\hline \multirow{2}{*}{$\mathrm{pH}$} & Rainy & 5.7 & 6.5 & 6.9 & 5.5 & 5.8 & 6.9 & 6.5 & 5.9 \\
\hline & Dry & 5.9 & 6.5 & 7.1 & - & 5.9 & 7.1 & 6.7 & 5.9 \\
\hline \multirow{2}{*}{ Colif. termot.(MPN L ${ }^{-1}$ ) } & Rainy & 740 & 9620 & 3867 & 103 & 12 & 5867 & 3540 & 733 \\
\hline & Dry & 7313 & 10200 & 2507 & - & 2 & 1333 & 1193 & 200 \\
\hline \multirow{2}{*}{$\mathrm{DO}\left(\mathrm{mg} \mathrm{L}^{-1}\right)$} & Rainy & 1.80 & 3.10 & 3.39 & 3.66 & 3.31 & 4.35 & 3.17 & 2.76 \\
\hline & Dry & 1.55 & 2.79 & 3.01 & - & 3.28 & 4.87 & 3.56 & 3.32 \\
\hline \multirow{2}{*}{$\mathrm{BOD}\left(\mathrm{mg} \mathrm{L}^{-1}\right)$} & Rainy & 1.55 & 3.96 & 1.68 & 4.18 & 3.34 & 7.51 & 1.06 & 2.32 \\
\hline & Dry & 1.48 & 5.71 & 2.88 & - & 2.52 & 6.72 & 1.84 & 1.92 \\
\hline \multirow{2}{*}{$\mathrm{N}\left(\mathrm{mg} \mathrm{L}^{-1}\right)$} & Rainy & 0.23 & 0.64 & 0.28 & 1.13 & 0.17 & 2.88 & 0.33 & 0.48 \\
\hline & Dry & 0.43 & 2.23 & 0.07 & - & 0.57 & 1.77 & 0.07 & 1.07 \\
\hline \multirow{2}{*}{$\mathrm{PO}_{4}^{3-}\left(\mathrm{mg} \mathrm{L}^{-1}\right)$} & Rainy & 0.59 & 0.17 & 0.30 & 0.33 & 0.35 & 0.40 & 0.27 & 0.39 \\
\hline & Dry & 0.35 & 1.21 & 0.11 & - & 0.24 & 0.53 & 0.30 & 0.48 \\
\hline
\end{tabular}

PS: micro-basin under pasture (spring); Ple: micro-basin under pasture (lentic environment); Plo: micro-basin under pasture (lotic environment); RU: micro-basin under reforestation (underground water); FU: micro-basin under forest (underground water); Fle: micro-basin under forest (lentic environment); Cle: micro-basin under coffee plantation (lentic environment); CS: micro-basin under coffee plantation (spring).

(and only in the sampling carried out during February and April). In this same micro-basin, Bertossi et al. (2013) conducted a water quality study in 2011 , where it was possible to collect underground as well as superficial water during dry and rainy periods. An important fact to be highlighted is that the area was still covered by pasture during the study period with the presence of goats, sheep and cattle. The results of Bertossi et al. (2013) and from the present study point to a notable reduction in water availability in this area which may have been influenced by below-average precipitation in 2014, and by the planting of a tree species that had a positive role in mitigating the effects of surface run off. These however, also reduced the spring's supply due to increased evapotranspiration. Castro \& Lopes (2001) argue that when evapotranspiration is greater than the annual precipitation with a more notable effect in some months of the dry season, cultivation of some plants can reduce spring water volume.

Regarding the variables, a general trend toward higher turbidity and total solids values in the rainy period was verified at most water collection sites, as also observed by Franco \& Hernandez (2009), which may be due to rainwater transporting larger amounts of sediments into the springs, elevating turbidity and total solids. However, lotic and lentic environments of the micro-basin under pasture showed inverse behavior, with higher values during dry periods. This occurred because cattle had free access to these waters (as also observed by the high values of coliforms), associated with the fact that in periods with less rainfall, spring flow and water courses are reduced (Valente \& Gomes, 2004), which can result in higher sediment concentration, and consequently higher turbidity.

Turbidity values measured were within the limits established by CONAMA Resolution 357 for classes 2 and 3 (Brasil, 2005), except for the points Ple (dry period) and RU, which presented values greater than 100 UNT. In the first case, as mentioned above, the high values may have been due to the tendency for sediment concentration during the dry period, especially in lentic environments, in addition to the presence of cattle. In the second case, the well at a shallow depth (approximately 1.5 meters), resembling subsurface run off waters, probably influenced water quality since soil has a filtering function retaining sediment from deeper layers (Amaral et al., 2003). 
When comparing exclusively the micro-basins, the lowest turbidity and total solids values were found in those under forest and coffee plantation, reinforcing the importance of forests in reducing sedimentary supply to water on one hand, and the consequent decrease in turbidity described in other studies such as by Donadio et al. (2005), Fernandes et al. (2014) and Tucci \& Clarke (1997), on the other. Micro-basin waters under forest and coffee plantation regimes showed little variation in these two variables during rainy and dry periods due to the presence of vegetation, which reduces surface runoff and sediment transport into the micro-basins.

On the other hand, the highest turbidity and total solids values were found for the underground water of the micro-basin under reforestation.

The water temperature ranged from $25.7^{\circ} \mathrm{C}$ to $28.7^{\circ} \mathrm{C}$ in the rainy period, and from $22.4^{\circ} \mathrm{C}$ to $25.8^{\circ} \mathrm{C}$ in the dry period. All points showed a tendency for lower values in the dry period, probably influenced by the lower air temperatures in the region since they correspond to the period between the months of June to October. Regarding the springs, the mean values for the micro-basin under coffee plantation were very close to those under pastures. This trend was also observed by Pinto et al. (2012) when analyzing springs under the same type of soil in a different region.

Among the areas studied, the $\mathrm{pH}$ reached values from 5.5 to 6.9 and from 5.9 to 7.1 in the rainy and dry periods, respectively. By analyzing each point individually, a slight variation during the year was observed, with values for groundwater, surface water and springs within the range of variation found by Menezes et al. (2013), Bertossi et al. (2013) and Agrizzi (2012), respectively, who conducted studies with waters in the same municipality as the present study. Spring and underground environments presented lower $\mathrm{pH}$. The waters from the other environments remained within the optimal standards within the range of 6 to 9 , as established by CONAMA Resolution $\mathrm{n}^{\circ} 357$ (Brasil, 2005).

Thermotolerant coliforms ranged from $12 \mathrm{MPN} \mathrm{L}^{-1}$ to $9.620 \mathrm{MPN} \mathrm{L}^{-1}$ in the rainy period and from $2 \mathrm{MPN} \mathrm{L}^{-1}$ to $10.200 \mathrm{MPN} \mathrm{L}^{-1}$ in the dry period. The highest values were observed in the micro-basin under pasture, including the spring, which results from the presence of cattle throughout the year. The presence of these animals found close to the spring could explain the high concentration at this point in the dry period. In the same municipality, Agrizzi (2012) also observed high total coliforms values in springs with presence of cattle. Likewise, in analyzing the water quality between agricultural land and a wildlife conservation zone, Pereira et al. (2012) found that the former presented higher values in relation to the latter due to the presence of cattle in the agricultural area.

Dissolved oxygen (DO) ranged from $1.80 \mathrm{mg} \mathrm{L}^{-1}$ to $4.35 \mathrm{mg} \mathrm{L}^{-1}$ in the rainy period, and from $1.55 \mathrm{mg} \mathrm{L}^{-1}$ to $4.87 \mathrm{mg} \mathrm{L}^{-1}$ in the dry period. Spring and underground water $\mathrm{DO}$ values were lower in each micro-basin, a characteristic inherent to this type of water (Agrizzi, 2012). In the micro-basin under pasture, higher values were observed at the Plo site in comparison with the Ple site, which is due to the higher water velocity in the lotic environment which favors atmospheric oxygen transfer to the water by diffusion processes, as also reported by Arcova \& Cicco (1999). The micro-basin under forest presented higher $\mathrm{DO}$ values compared to the others, as also reported by Pereira et al. (2012). The ideal minimum concentration for DO is $5 \mathrm{mg} \mathrm{L}^{-1}$ according to CONAMA Resolution No. 357 for class 2 (Brasil, 2005). Thus, all the collection points had low DO values. The presence of thermotolerant coliforms in all collection points may have influenced the results, since microorganisms use oxygen to degrade organic matter. The micro-basin under pasture, for example, had the highest rates of coliforms and the lowest $\mathrm{DO}$ values.

BOD ranged from $1.06 \mathrm{mg} \mathrm{L}^{-1}$ to $7.51 \mathrm{mg} \mathrm{L}^{-1}$ in the rainy period and from $1.48 \mathrm{mg} \mathrm{L}^{-1}$ to $6.72 \mathrm{mg} \mathrm{L}^{-1}$ in the dry period. $\mathrm{BOD}$ values for the micro-basin under pasture tended to be higher in the dry period, as evidenced by Souza (2011) who monitored the water quality of a micro-basin under pasture of the same sub-basin as the present study. In this case, the concentration of organic matter during the dry season, including bovine feces, increased BOD. Only the PS, Cle, Plo (rainy period) and CS (dry period) points had BOD values below $2.00 \mathrm{mg} \mathrm{L}^{-1}$ (reference value), indicating unpolluted water in relation to this variable. The high values measured in the lentic environment of the forest basin could be the result of decomposing leaves and fruit that fall from the trees and that are transported to the water, similar to what was observed in the same micro-basin by Bertossi et al. (2013). Lower BOD 
values were observed for underground and spring waters compared to surface water for all micro-basins.

Total nitrogen ranged from $0.17 \mathrm{mg} \mathrm{L}^{-1}$ to $2.88 \mathrm{mg} \mathrm{L}^{-1}$ in the rainy period and from $0.07 \mathrm{mg} \mathrm{L}^{-1}$ to $2.23 \mathrm{mg} \mathrm{L}^{-1}$ in the dry period. An oscillation in the total $\mathrm{N}$ concentration was observed in the micro-basin under pasture along the watercourse. The highest values at the Ple point resulted from the tendency of lentic environments to concentrate sediment and elements in the water. This can also be observed in the lentic environment of the micro-basin under forest. By comparing the micro-basins, those under pasture and forest had the highest total nitrogen values, which is partly due to the presence of cattle in the first area and to wild animals in the second. This corroborates Agrizzi (2012), who found higher total nitrogen values in micro-basins, which were predisposed to a greater circulation of animals.

In the study areas, $\mathrm{PO}_{4}^{3-}$ ranged from $0.17 \mathrm{mg} \mathrm{L}^{-1}$ to $0.59 \mathrm{mg} \mathrm{L}^{-1}$ in the rainy period and from $0.11 \mathrm{mg} \mathrm{L}^{-1}$ to $1.21 \mathrm{mg} \mathrm{L}^{-1}$ in the dry period. The phosphate level analysis can be related to the $\mathrm{DO}$ variable, as described by Esteves (1998). According to this author, phosphate ions can be released into the water column under low oxygen concentrations or anaerobic conditions. This relationship becomes more evident at the Ple point, where a higher $\mathrm{PO}_{4}^{3-}$ value was observed in comparison to the other collection sites, which was coincident with the lowest DO values at this point. Phosphorus concentration varied little between the micro-basins, with the exception of the Ple point, as mentioned.

By analyzing the results of Souza (2011), when the micro-basin under reforestation was still covered by pasture, it was possible to notice differences in the results between different uses. In that study, total $\mathrm{P}$ concentration was $0.07 \mathrm{mg} \mathrm{L}^{-1}$ in the rainy season; therefore lower than that found in the present study. The increase in total $\mathrm{P}$ values may be related to the presence of a forest, which favors the presence of organic matter such as leaves, branches and fruit. In analyzing the same micro-basins under forest and coffee plantations, the same author found superficial water values equal to 0.13 and $0.08 \mathrm{mg} \mathrm{L}^{-1}$ for the first area, and equivalent to 0.11 and $0.03 \mathrm{mg} \mathrm{L}^{-1}$ for the second during dry and rainy periods, respectively. In the underground water under forest area, they found 0.15 and $0.03 \mathrm{mg} \mathrm{L}^{-1}$ of total phosphorus for dry and rainy periods. By comparing these results with the present research, an increase in values is observed. This may also be due to the presence of organic matter deposited over time that gradually increased phosphorus levels.

WQI $_{\text {CETESB }}$ values ranged from 30 to 70 , therefore falling between the good and bad classes, as shown in Table 2.

It can be observed that among the studied micro-basins, the area under forest had the highest WQI's, followed by micro-basins under coffee plantation, pasture and reforestation, respectively. Similarly, in analyzing

Table 2. Water quality indexes (WQI ${ }_{\text {CETESB }}$ ) of surface and underground waters of the studied micro-basins.

\begin{tabular}{|c|c|c|c|c|}
\hline Microbasin & Sampling point & Period & WQI $_{\text {CETESB }}$ & Class \\
\hline \multirow{6}{*}{ Pasture } & \multirow{2}{*}{ Spring (PS) } & Dry & 49 & fair \\
\hline & & Rainy & 55 & good \\
\hline & \multirow{2}{*}{ Lentic (Ple) } & Dry & 30 & bad \\
\hline & & Rainy & 42 & fair \\
\hline & \multirow{2}{*}{ Lotic (Plo) } & Dry & 53 & good \\
\hline & & Rainy & 54 & good \\
\hline \multirow{2}{*}{ Reforestation area } & \multirow{2}{*}{ Underground (RU) } & Dry & - & - \\
\hline & & Rainy & 43 & fair \\
\hline \multirow{4}{*}{ Forest } & \multirow{2}{*}{ Underground (FU) } & Dry & 70 & good \\
\hline & & Rainy & 53 & good \\
\hline & \multirow{2}{*}{ Lentic (Fle) } & Dry & 62 & good \\
\hline & & Rainy & 58 & good \\
\hline \multirow{4}{*}{ Coffee plantation } & \multirow{2}{*}{ Spring (CS) } & Dry & 59 & good \\
\hline & & Rainy & 57 & good \\
\hline & \multirow{2}{*}{ Lentic (Cle) } & Dry & 58 & good \\
\hline & & Rainy & 54 & good \\
\hline
\end{tabular}


micro-basins under different soil uses, Pinto et al. (2012) found the same sequence of water quality.

The sampling point in the reforestation micro-basin was classified as fair quality. Bertossi et al. (2013) studied this same area and classified the underground water in the rainy period as good, however this area was covered by pasture. The degradation of water quality may have mainly been due to sediment becoming more concentrated given the aforementioned reduction of water availability, thereby increasing turbidity and solid values at this sampling point. For this micro-basin, the previous pasture situation presented better WQI. However, the beneficial functions of the forest, especially for water quality, are considerable, which leads us to conclude that the preponderant factor in this case was the recent management operations carried out in the area. The depth of the well of this micro-basin may have also influenced the WQI. This was also observed by Scalize et al. (2014) who found lower water quality in shallow wells, with the monitoring well used by Bertossi et al. (2013) being deeper and in a different location to that used in the present study.

In spite of the good classification of the WQI's for most collection points, the analysis comparing the data with the normative standards showed that all the collection sites presented some type of nonconformity with legislation, especially regarding their use for human consumption, according to Ordinance No. 2.914/11 (Brasil, 2011).

The turbidity at the PS, CS and FU sampling points remained within or near to potability standards ( $\leq 5.0$ UNT), differing from points downstream (Ple, Plo, Cle and Fle) which exceeded the aforementioned limits, evidencing the effect of these soil coverages on water quality in the study area. The underground water samples from the reforestation area remained outside the maximum values allowed by the resolution CONAMA no 396 (Brasil, 2008). However, this result may have been influenced by the shallow depth of the well, as already mentioned.

The presence of thermotolerant coliforms was verified at all points, being in disagreement with the legislation (Brasil, 2011) which determines them unfit for human consumption. The micro-basin under pasture presented values farther from those required, followed by the basins under forest, coffee plantation and reforestation, with the latter only being sampled twice during the rainy period, and only from the well. Resolutions CONAMA n ${ }^{\circ} 357 / 05$ (Brasil, 2005) and CONAMA no 396 (Brasil, 2008) establish broader limits for thermotolerant coliforms, allowing water to be used for different purposes. Underground water samples from micro-basins under reforestation and forest (in the rainy period), for example, exceeded water potability limits, yet they proved suitable for other uses: animal consumption (with values $\leq 200 \mathrm{mg} \cdot \mathrm{L}^{-1}$ ) and recreation (with values $\leq 1.000 \mathrm{mg} \cdot \mathrm{L}^{-1}$ ).

According to the resolution CONAMA no 357 (Brasil, 2005) which legislates regarding surface water, the water from the micro-basins under forest lentic environment (FLe) and micro-basin under pasture (PLe) in the dry period did not meet the limits proposed for BOD in class 2 , however they were within the limits proposed for Class 3. Other points, including underground water, maintained values within the permitted range $\left(\leq 5.0 \mathrm{mg} \mathrm{L}^{-1}\right)$. Similar to that found in the present study, Menezes et al. (2009) found a higher frequency of nonconformity with the norms regarding BOD for lakes, rivers and dams, while presenting a lower frequency for underground spring waters. This is because environments related to the former group are more exposed to the entry of organic matter and a consequent decrease of oxygen.

Regarding $\mathrm{pH}$ values, all three regulations determine $\mathrm{pH}$ ranges between 6 and 9 as ideal for human consumption. Thus, the analyses showed that all the points corresponding to spring and underground waters did not meet normative standards, with values below 6 . The other sampling points met the $\mathrm{pH}$ range required by law. In analyzing 20 wells in the city of Alegre, Menezes et al. (2013) found that $18.33 \%$ presented $\mathrm{pH}$ below the limits established by Ordinance No. 2.914/11 (Brasil, 2011). However, according to Eaton et al. (2005), values outside the proposed limits are not indicative of waters posing health risks since they are within normal limits for natural waters ( $\mathrm{pH} 4$ to 9).

The low DO values measured were compatible with Class 4, except for the FLe point, which presented DO within the limits for class 3 according to Resolution CONAMA no 357 (Brasil, 2005).

The results show that in spite of the usefulness of WQI together information in order to more clearly convey it to the public, this index may underestimate or overestimate water quality. Therefore, individually evaluating the 
variables is very important to analyze/understand the behavior of all variables involved.

\section{CONCLUSIONS}

According to the WQI values, the best water quality indexes were found in the micro-basin under forest, followed by the indexes obtained in micro-basins under coffee plantation and pasture.

WQIwere best in the dry period for the micro-basins under forest and coffee plantation regimes, and best in the rainy period for the micro-basin under pasture.

\section{ACKNOWLEDGEMENTS}

The authors thank "Fundação de Amparo à Pesquisa do Espírito Santo - FAPES” for the undergraduate research scholarship and the "Conselho Nacional de Desenvolvimento Científico e Tecnológico - CNPq" for a research productivity fellowship (process number 306090/2013-9) and financial support (process number 479954/2012-7).

\section{SUBMISSION STATUS}

Received: 19 dec., 2016

Accepted: 26 july, 2017

\section{CORRESPONDENCE TO}

\section{Milena Scaramussa Pastro}

Departamento de Ciências Florestais e da Madeira, Universidade Federal do Espírito

Santo - UFES, Av. Governador Lindemberg, 316 , Centro, CEP 29550-000, Jerônimo Monteiro, ES, Brasil

e-mail: milenascaramussa@hotmail.com

\section{FINANCIAL SUPPORT}

\section{FAPES.}

\section{REFERENCES}

Agência Nacional das Águas - ANA. Indicadores de qualidade: Índice de Qualidade das Águas (IQA) [online]. Brasília: ANA; 2014. [cited 2014 Dec 3]. Available from: http://portalpnqa.ana.gov.br/indicadores-indice-aguas.aspx
Agrizzi DV. Índice de qualidade de nascentes no assentamento Paraíso, Alegre, ES [dissertação]. Jerônimo Monteiro: Universidade Federal do Espírito Santo; 2012.

Almeida MAB, Schwarzbold A. Avaliação sazonal da qualidade das águas do Arroio da Cria Montenegro, RS com aplicação de um índice de qualidade de água (IQA). Revista Brasileira de Recursos Hídricos 2003; 8(1): 81-97. http://dx.doi.org/10.21168/rbrh.v8n1.p81-97.

Alvares CA, Stape JL, Sentelhas PC, Gonçalves JLM, Sparovek G. Köppen's climate classification map for Brazil. Meteorol Zeitschrift 2013; 22(6): 711-728. http://dx.doi. org/10.1127/0941-2948/2013/0507.

Amaral LA, Nader A Fo, Rossi OD Jr, Ferreira LA, Barros LSS. Água de consumo humano como fator de risco à saúde em propriedades rurais. Revista de Saude Publica 2003; 37(4): 510-514. http://dx.doi.org/10.1590/S003489102003000400017. PMid:12937713.

Arcova FCS, Cicco V. Qualidade da água de microbacias com diferentes usos do solo na região de Cunha, Estado de São Paulo. Scientia Forestalis 1999;(56): 125-134.

Associação Brasileira de Normas Técnicas - ABNT. NBR 9898: preservação e técnicas de amostragem de afluente líquidos e corpos receptores: procedimento. Rio de Janeiro: ABNT; 1987.

Associação Brasileira de Normas Técnicas - ABNT. NBR 10664: água: determinação de resíduos (sólidos): método gravimétrico: método de ensaio. Rio de Janeiro: ABNT; 1989.

Associação Brasileira de Normas Técnicas - ABNT. NBR 12614: água: determinação da demanda bioquímica de oxigênio (DBO): método de incubação $\left(20^{\circ} \mathrm{C}\right.$, cinco dias): método de ensaio. Rio de Janeiro: ABNT; 1992.

Batalha SSA, Martorano LG, Biase AG, Morales GP, Pontes AN, Santos LS. Condições físico-químicas e biológicas em águas superficiais do Rio Tapajós e a conservação de Floresta Nacional na Amazônia, Brasil. Revista Ambiente \& Água 2014; 9(4): 647-663. http://dx.doi.org/10.4136/ ambi-agua.1304.

Bertossi APA, Cecílio RA, Neves MA, Garcia GO. Qualidade da água em microbacias hidrográficas com diferentes coberturas do solo no sul do Espírito Santo. Revista Árvore 2013; 37(1): 107-117. http://dx.doi.org/10.1590/ S0100-67622013000100012.

Brasil. Ministério do Meio Ambiente. Lei $n^{\circ}$ 9433, de 8 de janeiro de 1997. Diário Oficial da República Federativa do Brasil, Brasília, DF (1997 jan.): 470.

Brasil. Ministério do Meio Ambiente. Conselho Nacional do Meio Ambiente. Resolução no 357, de 17 de março de 2005. Diário Oficial da República Federativa do Brasil, Brasília, DF (2005 mar.); Sec 1: 58-63.

Brasil. Ministério do Meio Ambiente. Conselho Nacional do Meio Ambiente. Resolução no 396, de 3 de abril de 2008. Diário Oficial da República Federativa do Brasil, Brasília, DF (2008 abr. 7); Sec 1: 64-68. 
Brasil. Ministério da Saúde. Portaria $n^{\circ}$ 2914, de 12 de dezembro de 2011. Diário Oficial da República Federativa do Brasil, Brasília, DF (2011 dez.): 39.

Castro PS, Lopes JDS. Recuperação e conservação de nascentes. Viçosa: Centro de Produções Técnicas; 2001.

Companhia Ambiental do Estado de São Paulo - CETESB. IQA: Índice de Qualidade das Águas [online]. São Paulo: CETESB; 2014. [cited $2014 \mathrm{Dec} 3$ ]. Available from: http:// www.cetesb.sp.gov.br/agua/\%C3\%81guasSuperficiais/42\%C3\%8Dndice-de-Qualidade-das\%C3\%81guas-\%28iqa\%29

Donadio NMM, Galbiatti JA, Paula RC. Qualidade da água de nascentes com diferentes usos do solo na bacia hidrográfica do Córrego Rico, São Paulo, Brasil. Engenharia Agrícola 2005; 25(1): 115-125. http://dx.doi.org/10.1590/ S0100-69162005000100013.

Eaton AD, Clesceri LS, Rice EW, Greenberg AE. Standard methods for the examination of water and wastewater.21. ed. Washington: APHA/AWWA/WEF; 2005.

Esteves FA. Fundamentos de limnologia. Rio de janeiro: Interciência/FINEP; 1998.

Fernandes MM, Carvalho DF, Ceddia MB, Francelino MR. Valoração ambiental do efeito externo da erosão em duas sub-bacias com diferentes percentuais de mata atlântica. Bioscience Journal 2014; 30(2): 411-420.

Franco RAM, Hernandez FBT. Qualidade da água para irrigação na microbacia do Coqueiro, Estado de São Paulo. Revista Brasileira de Engenharia Agrícola e Ambiental 2009; 13(6): 772-780. http://dx.doi.org/10.1590/S141543662009000600016.

Menezes JM, Prado RB, Silva GC Jr, Mansur KL, Oliveira LS. Qualidade da água e sua relação espacial com as fontes de contaminação antrópicas e naturais: bacia hidrográfica do Rio São Domingos - RJ. Revista de Engenharia Agrícola 2009; 29(4): 687-698. http://dx.doi.org/10.1590/S010069162009000400019.

Menezes JPC, Bertossi APA, Santos AR, Neves MA. Qualidade da água subterrânea para consumo humano e uso agrícola no sul do Estado do Espírito Santo. Revista Eletrônica em Gestão. Educação e Tecnologia Ambiental 2013; 17(17): 3318-3326.
Perazzoli M, Pinheiro A, Kaufmann V. Efeitos de cenários de uso do solo sobre o regime hídrico e produção de sedimentos na bacia do Ribeirão Concórdia - SC. Revista Árvore 2013; 37(5): 859-869. http://dx.doi.org/10.1590/ S0100-67622013000500008.

Pereira PS, Fernandes LAC, Oliveira JLM, Baptista DF. Avaliação da integridade ecológica de rios em áreas do zoneamento ecológico econômico do complexo hidrográfico Guapiaçu-Macacu, RJ, Brasil. Revista Ambiente \& Água 2012; 7(1): 157-168. http://dx.doi.org/10.4136/ambi-agua.762.

Pinto LVA, Roma TN, Balieiro KRC. Avaliação qualitativa da água de nascentes com diferentes usos do solo em seu entorno. Cerne 2012; 18(3): 495-505. http://dx.doi. org/10.1590/S0104-77602012000300018.

Scalize PS, Barros EFS, Soares LA, Hora KER, Ferreira NC, Baumann LRF. Avaliação da qualidade da água para abastecimento no assentamento de reforma agrária Canudos, Estado de Goiás. Revista Ambiente \& Água 2014; 9(4): 696-707. http://dx.doi.org/10.4136/ambi-agua.1386.

Souza APAB. Índice de qualidade da água em microbacias hidrográficas com diferentes coberturas vegetais, no sul do Estado do Espírito Santo [dissertação]. Jerônimo Monteiro: Universidade Federal do Espírito Santo; 2011.

Tucci CEM, Clarke RT. Impactos das mudanças da cobertura vegetal no escoamento: revisão. Revista Brasileira de Recursos Hídricos 1997; 2(1): 135-152. http://dx.doi. org/10.21168/rbrh.v2n1.p135-152.

Valente OF, Gomes MA. Conservação de nascentes: hidrologia e manejo de bacias hidrológicas de cabeceiras. Viçosa: Aprenda Fácil; 2004.

Vanzela LS, Hernandez FBT, Franco RAM. Influência do uso e ocupação do solo nos recursos hídricos do Córrego Três Barras, Marinópolis. Revista Brasileira de Engenharia Agrícola e Ambiental 2010; 14(1): 55-64. http://dx.doi. org/10.1590/S1415-43662010000100008.

Von Sperling M. Introdução a qualidade da água e ao tratamento de esgotos. 3. ed. Belo Horizonte: DESA/ UFMG; 2005. 452 p. 